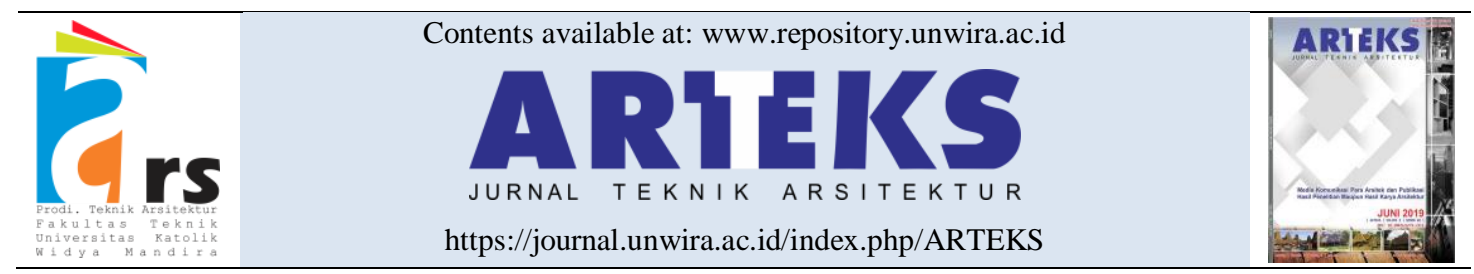

Research paper

doi: http://doi.org/10.30822/arteks.v4i1.359

\title{
Evaluasi active design pada media perjalanan aktif di sekitar ruang publik kota
}

\section{Raden Rangga Ilham Irfandian, Herman Wilianto*}

Program Studi Magister Arsitektur, Fakultas Teknik, Universitas Katolik Parahyangan Jl. Merdeka, No. 30, Bandung, Indonesia

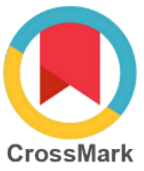

\begin{tabular}{l}
\hline ARTICLE INFO \\
\hline Article history: \\
Received September 06, 2019 \\
Received in revised form Sept. 18, 2019 \\
Accepted October 27, 2019 \\
Available online December 16, 2019
\end{tabular}

\section{Keywords: \\ Active design \\ Evaluation design \\ Healthy city \\ Public space \\ Urban open space}

*Corresponding author: Herman Wilianto
Program Studi Magister Arsitektur, Fakultas
Teknik, Universitas Katolik Parahyangan,
Indonesia
Email: drhermanw@gmail.com

\author{
ABSTRACT \\ The active design evaluation on the media of active living around \\ urban public space
}

The rise of development, technology and culture in urban communities has produced various positive and negative impacts, one of the negative impacts is the decline in public health factors and the increase of various cardiovascular diseases in urban communities caused by sedentary lifestyle. Based on this phenomenon we began to develop the Active Design principle. The active design is a design principles to makes some environment that can stimulate its users to carry out physical activity naturally. The active design principles has a significant impact on improving public health factors when applied around the centre of communities activities. Along with this phenomenon, the city of Bandung has carried out various revitalization on its public open spaces, one of which is revitalization in the Saparua Park, which has become the centre of community activities in sports and recreation. This is a qualitative-descriptive study with the aim of evaluation. The research begins by formulating active design indicators from various literatures, then evaluating the object of study based on the indicators. Produce an understanding of the extent to which the principles of active design materialize on the object of study, the potential for future development and any manifestations that can be used as examples for design elsewhere.

\section{Pendahuluan}

Perkembangan pembangunan pada wilayah perkotaan secara global telah menghasilkan pelbagai dampak positif maupun juga negatif bagi kondisi lingkungan dan kehidupan manusia (Subroto 2019; Pradono 2019). Salah satu dampak negatif tersebut adalah menurunnya kesehatan masyarakat perkotaan akibat pola hidup yang minim melakukan aktivitas fisik atau sedentary lifestyle (Widodo 2019; Hendrawan and Dwisusanto 2017). Pada tahun 2008 WHO menyimpulkan bahwa terdapat kurang lebih 3.2 juta kematian per-tahun yang diakibatkan oleh kurangnya aktivitas fisik (WHO 2011). Pada saat ini baik bidang perancangan arsitektur maupun perancangan kota lebih banyak menghasilkan ruang kota yang mendukung gaya hidup sedentary dibandingkan dengan gaya hidup aktif pada kegiatan sehari-hari masyarakat perkotaan (Lee 2012). Tata fisik lingkungan kota pada saat ini harus dapat mendukung-memicu masyarakat untuk aktif bergerak secara fisik, sehingga tercipta gaya hidup active living yang dapat menunjang faktor kesehatan publik (Centers for Disease Control and Prevention 2014). Kota yang sehat memiliki pergerakan aktif, berjalan dan bersepeda sebagai pola pergerakan alami dalam 
kehidupan sehari-hari (Gehl 2007). Berkaitan dengan hal ini, Perserikatan Bangsa-Bangsa (PBB) telah merumuskan berbagai program pengembangan wilayah permukiman pada wilayah perkotaan melalui United Nation Human Settlements Programme (Martin and Martin 2007). Seiring dengan isu dari rumusan tersebut berkembanglah berbagai konsep perancangan dan pengembangan wilayah perkotaan di seluruh dunia, salah satunya adalah konsep healthy cities (kota sehat) (Kamel Boulos and Al-Shorbaji 2014; Pucher and Buehler 2010; Giles-Corti et al. 2014). Pola perilaku aktif pada masyarakat urban dapat ditunjang melalui tata fisik lingkungan yang secara khusus dirancang untuk dapat meningkatkan aktivitas pergerakan fisik para penggunanya, prinsip dikenal dengan istilah desain aktif atau active design (Jackson 2003). Berdasarkan pandangan kuantitas dan signifikansi, prinsip desain aktif akan efektif memperbaiki faktor kesehatan publik apabila diterapkan pada ruang-ruang kota terlebih pada ruang terbuka publik, mengingat ruang terbuka publik merupakan salah satu wadah aktivitas keseharian dan rekreasi yang selalu ramai dikunjungi masyarakat perkotaan (Liem and Lake 2018). Sejalan dengan pemikiran bahwa selain memiliki fungsi bagi faktor ekonomi, sosial dan lingkungan, ruang terbuka publik juga memiliki fungsi bagi faktor kesehatan (Carmona, de Magalhães, and Hammond 2008, 7). Mengingat banyaknya potensi bagi pengembangan ruang kota, semenjak tahun 2013 secara perlahan Kota Bandung telah memperbaiki tata fisik lingkungannya, terutama pada taman-taman kota dan jalan-jalan protokol (Firdaus Prayogi, Isdianto, and Ihsan 2014). Di tengah fenomena revitalisasi taman kota, semenjak tahun 2015 Pemerintah Provinsi Jawa Barat juga melakukan revitalisasi terhadap taman Saparua Park yang juga berada di Kota Bandung. Pasca revitalisasi tersebut, hingga tahun 2018 Saparua Park terbagi menjadi dua area yaitu area lintasan olahraga dan area taman rekreasi. Penggabungan dua fungsi dominan tersebut menjadikan Saparua Park sebagai salah satu pusat kegiatan masyarakat dalam melakukan aktivitas fisik. Maka dari itu lingkungan mikro disekeliling Saparua Park yang memuat wadah bagi perjalanan aktif, meliputi: ruang pedestrian, ruang jalur sepeda dan transportasi massal menjadi obyek yang menarik dan tepat untuk diteliti bagi evaluasi desain aktif.

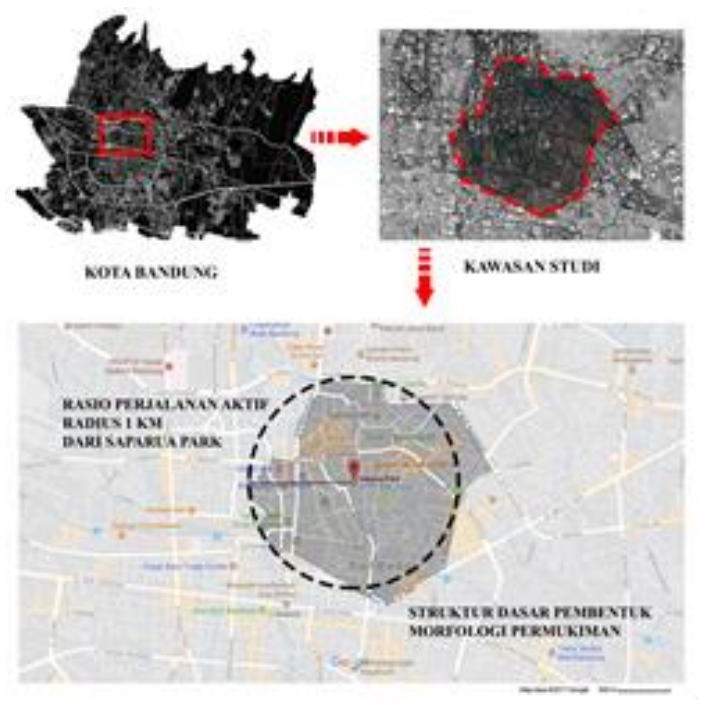

Gambar 1. Lokasi obyek studi, Saparua Park, kota Bandung, Provinsi Jawa Barat, Indonesia

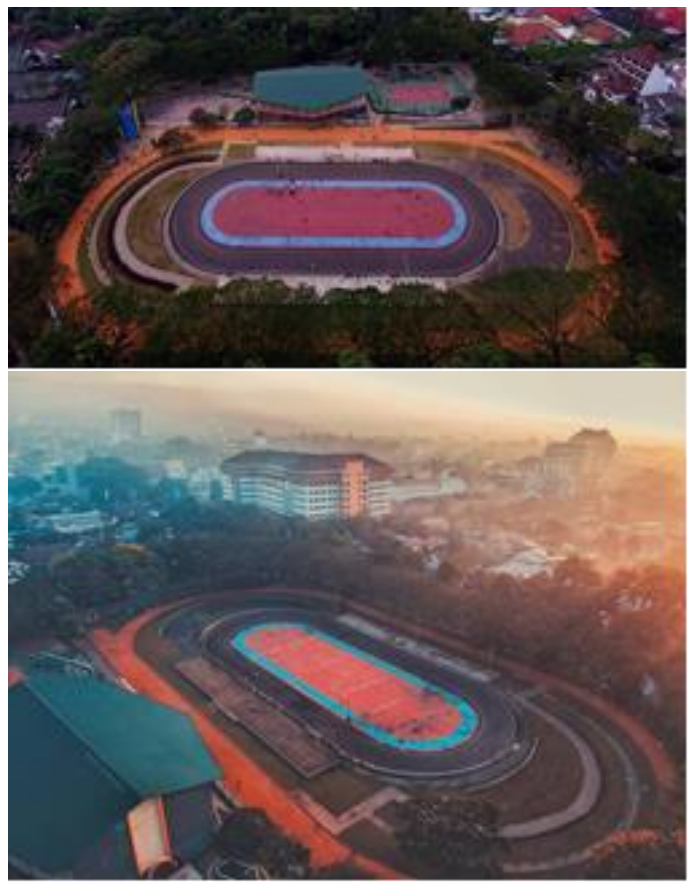

Gambar 2. Foto udara lingkungan sekitar, Saparua Park, Kota Bandung, Provinsi Jawa Barat, Indonesia

Tujuan dari penelitian ini adalah untuk mengetahui dan memperdalam pengatahuan tentang kondisi serta kualitas tata lingkungan fisik di sekitar ruang terbuka publik dalam membentuk gaya hidup aktif berdasarkan analisis evaluative, berdasarkan indikator dari pelbagai studi literatur terkait. Sedangkan manfaat dari penelitian ini adalah memberikan pandangan dan pemahaman ilmiah tentang perwujudan prinsip desain aktif 
pada ruang kota, khususnya pada konteks lingkungan di sekeliling ruang terbuka publik Saparua Park, Kota Bandung; memberikan pertimbangan perancangan baru dalam mengoptimalkan potensi ruang terbuka publik dan lingkungan di sekitarnya bagi peningkatan faktor kesehatan publik, khususnya bagi para perancang perkotaan, para arsitek, dan pemerintah di Indonesia.

\section{Metode penelitian}

Merupakan penelitian kualitatif bagi tujuan evaluasi. Dalam praktiknya menggunakan metode kualitatif, berlandaskan filsafat postivisme atau interpretatif. Metode ini digunakan agar mendapatkan data yang lengkap, dan informasi yang mendalam. Data didapatkan melalui observasi, wawancara, dan dokumentasi. Analisis data secara induktif, peneliti sebagai instrumen kunci, kemudian hasil analisis dijelaskan secara deskriptif argumentatif. Hasil penelitian bersifat deskriptif untuk mengkonstruksi fenomena dan menemukan fakta baru pada produk evaluasi. Secara terperinci. Penelitian dimulai dengan mempelajari serta memahami fenomena dan isu arsitektural yang sedang berkembang pada saat ini, kemudian melakukan eksplorasi dari berbagai sumber literatur maupun pengamatan langsung dilapangan sebagai observasi awal terhadap konteks healthy city, active living dan active design pada konteks ruang terbuka publik di wilayah perkotaan. Berdasarkan proses tersebut ditemukan pemahaman dasar bahwa desain aktif pada dasarnya merupakan pemanfaatan perpindahan gerak manusia dari satu titik terhadap titik lainnya pada ruang-ruang kota, dalam kata lain bagaimana kita merancang ruangruang yang berfungsi sebagai path untuk dapat terintegrasi terhadap keberadaan ruang terbuka publik yang berperan sebagai node (Lynch 1960; Watson, Plattus, and Shibley 2003). Ruang kota yang berperan sebagai path tersebut dapat dikatakan sebagai wadah atau media perjalanan aktif, meliputi: ruang pedestrian, ruang jalur sepeda dan transportasi massal. Kemudian bentukan dan tata fisik dari ketiga ruang tersebut dievaluasi melalui indikator desain aktif yang telah dirumuskan sebelumnya berdasarkan studi literatur. Pada akhirnya menghasilkan pemahaman akan kualitas pada objek studi, hal- hal yang dapat diperbaiki serta potensi bagi pengembangan kedepan.

\section{Temuan dan pembahasan}

\section{Desain aktif pada lingkungan di sekitar ruang terbuka publik}

Gaya hidup aktif atau active living adalah integrasi antara gerak fisik kedalam aktivitas sehari-hari, seperti berjalan kaki, bersepeda, menaiki tangga, dan menggunakan fasilitas rekreasional (WHO 2011). Pelbagai aktivitas tersebut tentu saja membutuhkan wadah, pada ruang kota berbagai aktivitas pergerakan fisik tersebut diwadahi oleh:

1. Jalur pedestrian;

2. Jalur sepeda, dan

3. Jalur transportasi umum.

Berdasarkan prinsip desain aktif, kita dapat menilai kualitas active living yang terbentuk pada objek penelitian dan memberi solusi alternatif dari wadah dan moda yang sudah ada agar aktivitas fisik dapat meningkat. Lingkungan binaan yang aktif akan berkontribusi terhadap gaya hidup aktif dan komunitas yang lebih sehat.

\section{Desain aktif pada ruang pedestrian}

Dalam perkembangan budaya perkotaan global, aktivitas berjalan kaki lebih dari sekedar perpindahan massa antar titik tujuan, namun pejalan kaki juga dapat berganti arah, mempercepat langkah, bermanuver, juga melakukan aktivitas pilihan seperti duduk dan beristirahat. Proses berjalan kaki menangkap kehidupan kota, "Life happens on foot" (Gehl 2007). Aktivitas berjalan kaki membutuhkan wadah yang dinamakan ruang pedestrian. Dalam membangun dan merancang lingkungan gerak yang aktif, jalur pedestrian merupakan wadah penting dan merupakan kebutuhan ruang mendasar bagi terciptanya gaya hidup aktif (Lefebvre 1992). Jalur pedestrian pada ruang kota berfungsi untuk menghubungkan berbagai tempat dengan fungsi berbeda, memberi perlindungan, kenyamanan, dan memberikan pengalaman yang menarik sebagai sarana rekreasi didalam ruang kota (Liem and Lake 2018; Mberu and Purbadi 2018). Dari pelbagai aspek kebutuhan berjalan kaki, terdapat tiga kriteria dasar pada kalur pedestrian yang wajib terpenuhi yaitu, perlindungan, kenyamanan, dan kesenangan (Gehl 2007). Secara umum, setiap manusia 
memiliki batas kemampuan jarak tempuh dalam berjalan kaki, batas fisik merupakan faktor yang paing menonjol dari pengalaman berjalan kaki. Menurut Gehl, batas fisik berjalan kaki seseorang dari satu titik tempat ke tempat lain pada ruang kota adalah 500-meter dengan waktu tempuh 6 menit. Apabila perjalanan diteruskan, batas maksimal kenyamanan berjalan kaki dalam ruang kota adalah 1.2-kilometer dengan waktu tempuh 12 menit.

\section{Tipologi ruang pedestrian}

Untuk mewadahi gerak berjalan kaki dan aktivitas pendukungnya maka jalur pedestrian harus memiliki lebar yang optimal. Dari active design shaping the sidewalk experience, besaran ruang pedestrian ditentukan oleh tipologi lingkungannya, tipologi tersebut dapat dibedakan menjadi tiga tipe sebagai berikut:

1. Downtown commercial street

Tipe lingkungan jalan seperti ini biasanya memiliki trotoar yang paling luas, dengan lebar ruang pedestrian sekitar $3-4.5$ meter. Memiliki sisi bangunan yang tinggi membingkai di sepanjang ruang jalan. Tipe ini mengakomodasi semua golongan pejalan kaki, termasuk para pekerja, pengguna transportasi umum transit, pengunjung pertokoan dari distrik lain, turis, dan para penduduk.

\section{Neighborhood main street}

Tipe lingkungan jalan seperti ini biasanya memiliki lebar ruang pedestrian antara 1.5 - 3.5 meter. Gedung-gedung di sepanjang jalur tingginya antara satu sampai empat lantai. Golongan pejalan kaki pada umumnya adalah campuran antara penduduk lokal, anak sekolah, pembeli, dan pekerja.

\section{Residental only street}

Tipe lingkungan jalan seperti ini memiliki jalur yang cenderung hening dari keramaian dan lebar yang sempit sekitar $1.5-2$ meter. Keberadaan pohon dan ruang tanaman merupakan elemen yang sering ada di pinggir ruang jalan seperti ini. Bangunan sebagian besar mundur dari garis tapak atau set-back. Pejalan kaki merupakan warga lingkungan.

\section{Pembagian zona ruang pedestrian}

Berdasarkan Urban Street Design Guide (2013), jalur pedestrian yang ideal terbagi dari 4 zona, setiap zona memiliki fungsi masing-masing (2013). Pembagian 4 zona ini dipisahkan berdasarkan 4 jenis aktivitas yang terjadi didalan kesatuan ruang pedestrian. Pembagian 4 zona tersebut yaitu:

1. Frontage zone;

2. Pedestrian through zone;

3. Street furniture zone;

4. Buffer zone.

\section{Desain aktif pada jalur sepeda}

Setelah berjalan kaki, bersepeda merupakan sarana transportasi aktif yang mudah dan paling sederhana, dengan bersepeda seseorang telah melakukan aktivitas gerak secara fisik sekaligus bertransportasi. Selain itu kebutuhan besaran ruang bagi aktivitas bersepeda lebih kecil dibandingkan dengan kebutuhan ruang mobil. Menurut NACTO (National Association of City Transportation Officials), pada jalan raya dengan volume lalu lintas tinggi serta jalanan dengan batas kecepatan lebih dari $35 \mathrm{mph}$, pertimbangkan desain berupa pemisahan jalur yang lebih jelas antara sepeda dan lalu lintas dapat dilakukan dengan:

1. Left-sided bike lanes;

2. Buffered bike lanes;

3. Cycle tracks.

Pada kasus studi, lingkungan Saparua Park dan sekitarnya telah memiliki jalur khusus sepeda dengan tipe left-side bike lane, maka tipe jalur inilah yang dievaluasi sesuai dengan kriteria ideal sebagai berikut (Anderson W G 1991):

1. Lebar jalur sepeda yang direkomendasikan adalah 1.5-meter dari permukaan trotoar atau pagar pembatas hingga jalur jalur sepeda. Jika permukaan tidak mulus maka lebar minimal 1.2-meter;

2. Pada jalan dengan ruang parkir mobil pada sisi jalan, jalur sepeda harus ditempatkan di antara area parkir dan jalur lalu lintas kendaraan, dengan lebar minimum 1.5-meter. Maka dari itu lebar keseluruhan ruang shared space yang mencakup ruang parkir mobil dan jalur khusus sepeda adalah 3.5-meter dari batas trotoar;

3. Pada sisi trotoar yang memiliki pagar, dianjurkan untuk memberi penambahan lebar minimum 0.6-meter;

4. Jalur sepeda harus memiliki garis pembatas dari jalur kendaraan bermotor, dengan garis putih solid 150-mm;

5. Pada jalan yang memiliki arus lalu lintas tinggi, garis putus-putus dipergunakan pada jalur sepeda.

Setelah jalur khusus sepeda mulai diterapkan, maka terdapat beberapa fasilitas dan pengembangan yang dapat menyusul untuk 
diterapkan pada jalur khusus sepeda. Berikut adalah beberapa indikator yang dianjurkan menurut Active Design New York dan Active Design Sport England dalam anjuran pengembangan fasilitas sepeda sebagai transportasi masyarakat perkotaan:

1. Menyediakan sarana prasarana penyewaan sepeda pada setiap taman kota maupun titiktitik tujuan penting pada kawasan kota;

2. Merancang perlintasan sepeda yang spesifik dengan tanda-tanda tertentu yang dapat dimengerti oleh para pejalan kaki, pengguna sepeda, kendaraan bermotor, dan perhentian bus;

3. Mengembangkan jalur hijau rekreasi khusus sepeda menjadi rute alternatif bagi pengguna sepeda yang terintegrasi dengan beberapa tempat atau ruang publik.

\section{Rute khusus perjalanan aktif antar ruang terbuka publik}

Setelah jalur pedestrian dan jalur sepeda tersedia, keduanya harus dapat menghubungkan berbagai taman kota antara satu sama lain, ataupun tempat-tempat penting lainnya. Dengan begitu jalur pedestrian dan jalur sepeda berfungsi sebagai ruang vital bagi kegiatan transportasi dan rekreasi masyarakat perkotaan. Hendaknya suatu kota memiliki jaringan khusus yang menghubungkan setiap titik ruang terbuka publik maupun tempat-tempat tujuan utama antara satu dengan yang lainnya. Berdasarkan pandangan prinsip active design, selain mewadahi fungsi perpindahan melalui aktivitas fisik seperti berjalan dan bersepeda (rekreasi), jalur khusus tersebut dapat juga dimanfaatkan bagi fungsi utilitas kota, seperti jalur sistem drainase berkelanjutan, pemanfaatan jalur rel kereta api yang sudah non-aktif, bahkan jalur hijau hutan kota dengan fungsi lanskap produktif (urban farming).

\section{Desain aktif pada fasilitas transportasi massal}

Perancang dapat meningkatkan kuantitas penggunaan transportasi umum dengan cara memperbaiki bentukan ruang akses transportasi umum maupun ruang fasilitas pendukungnya. Terdapat hubungan antara akses transit dengan pergerakan aktif, dimana sistem transit melibatkan aktivitas berjalan kaki. Perjalanan dari rumah di pagi hari menuju tempat tujuan aktivitas dengan menggunakan kendaraan umum adalah pengalaman active living, karena didalamnya terdapat walkabilitas. Dalam sisitem TOD
(Transit Oriented Development) walkabilitas ditentukan oleh bentukan ruang akses yang baik. Apabila membangun akses transportasi umum yang menarik dan benar maka peluang terciptanya gaya hidup active living pada keseharian masyarakat akan semakin terwujud. Berikut kriteria sistem transit yang dapat mendukung pergerakan aktif, diantaranya:

1. Perletakan halte transit dekat dengan entrance bangunan atau entrance ruang terbuka publik yang ada pada kawasan untuk menarik pengguna dan memudahkan orientasi;

2. Penempatan perhentian sarana transportasi massal terhubung dengan akses jalan raya yang terkoneksi antara satu dengan yang lainnya;

3. Setiap halte dilengkapi dengan papan informasi yang memuat: peta, lokasi, jarak, waktu, rute, dan iklan motivasi kesehatan;

4. Membuat area tepi/sisi jalan menuju halte nyaman untuk dilalui oleh para pejalan kaki, termasuk adanya kebutuhan akses bagi kaum difabel;

5. Halte dilengkapi oleh atap-tenda/shelter sehingga para pengguna terhindar dari hujan, terik matahari, dan angin.

Lingkungan Saparua Park merupakan sebuah cells persegi yang terbentuk dari empat ruas jalan yang mengelilinginya. Keempat ruas jalan tersebut yaitu Jalan Saparua pada sisi Barat, Jalan Ambon pada sisi Utara, jalan Banda pada sisi Timur, dan Jalan Aceh pada sisi Selatan. Lingkungan Saparua Park memiliki kontur yang relatif datar sebagai man made miniature of natures, sementara itu keempat ruas jalan yang mengelilinginya memiliki kontur yang berbedabeda, sehingga hubungan pada setiap ruas jalan terhadap Saparua Park memiliki dinamika ruang masing-masing.

\section{Dinamika ruang pedestrian Jalan Ambon sisi Saparua Park}

Termasuk tipologi neighborhood mainstreet dengan kepadatan sedang, maka standar lebar keseluruhan ruang pedestrian: $150 \mathrm{~cm}-350 \mathrm{~cm}$.

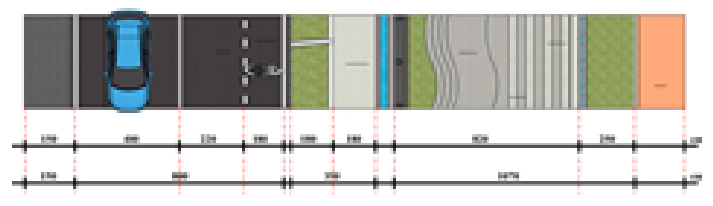




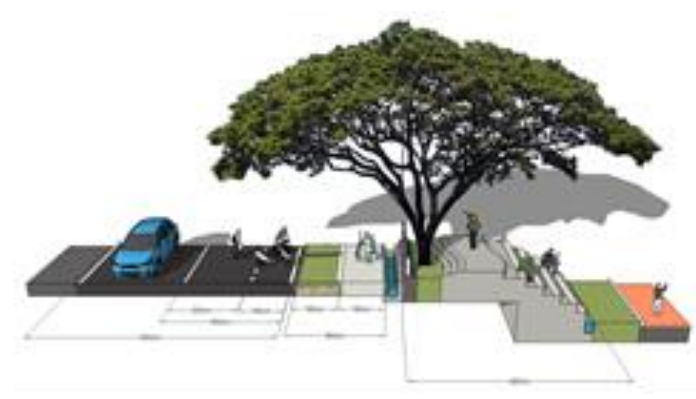

Gambar 3. Ilustrasi dinamika ruang pedestrian Jalan Ambon sisi Saparua Park, Kota Bandung, Provinsi Jawa Barat, Indonesia

Pada kondisi lapangan ruang pedestrian memiliki lebar keseluruhan $360 \mathrm{~cm}$, terdiri dari pedestrian through zone dan buffer zone.

Frontage zone: tidak terdefinisikan secara jelas karena tidak ada perbedaan pola lantai, karena zona pedestrian through zone memiliki lebar $180 \mathrm{~cm}$, dapat dikatakan bahwa frontage zone menyatu di dalamnya belum memenuhi standar.

Pedestrian through zone: memiliki lebar $180 \mathrm{~cm}$, sudah memenuhi standar. Namun tidak terdapat pola lantai pemandu atau guiding block untuk mempermudah para penyandang disabilitas. Pada kondisi nyata ruang ini dipadati oleh keberadaan pedagang kaki lima (PKL) sehingga menghalangi akses bagi para pejalan kaki.

Street furniture zone: tidak ditemukan ruang bagi penempatan street furniture, melainkan hanya terdapat zona pedestrian through zone dan buffer zone yang dipenuhi oleh keberadaan tendatenda dan kursi duduk milik para pedagang kaki lima (PKL).

Buffer zone: Berupa ruang yang diperuntukan bagi tanaman dengan lebar total $180 \mathrm{~cm}$, namun pada kondisi nyata ruang ini dipadati oleh keberadaan tenda-tenda dan gerobak pedagang kaki lima (PKL).

\section{Dinamika ruang pedestrian Jalan Saparua sisi Saparua Park}

Termasuk tipologi residental onlystreet dengan kepadatan rendah, maka standar lebar keseluruhan ruang pedestrian: $150 \mathrm{~cm}-200 \mathrm{~cm}$. Pada kondisi lapangan lebar keseluruhan ruang pedestrian $340 \mathrm{~cm}$, terdiri dari frontage zone, pedestrian through zone dan street furniture zone, kesatuan ruang pedestrian segmen Jalan Saparua ini sudah memenuhi standar, termasuk adanya perbedaan pola material elemen lantai.

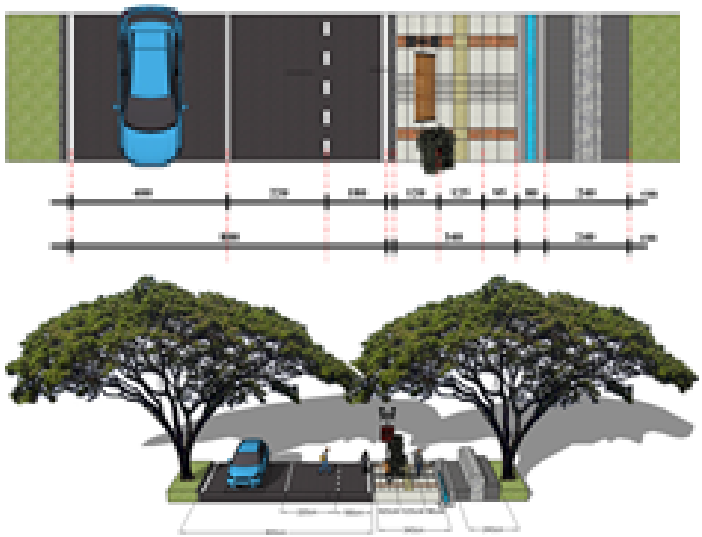

Gambar 4. Ilustrasi dinamika ruang pedestrian Jalan Saparua sisi Saparua Park, Kota Bandung, Provinsi Jawa Barat, Indonesia

Frontage zone: memiliki lebar $95 \mathrm{~cm}$, secara jelas jelas terdefinisi melalui perbedaan pola pada material lantai.

Pedestrian through zone: memiliki lebar $125 \mathrm{~cm}$, dilengkapi guiding block bagi penyandang disabilitas, sudah memenuhi standar.

Street furniture zone: memiliki lebar $120 \mathrm{~cm}$, sudah dilengkapi street furniture berupa kursi duduk, lampu penerangan dan pepohonan pada setiap jarak berkala, sudah memenuhi standar.

Buffer zone: zona ini tidak ditemukan, sudah sesuai kondisi lalu lintas pada Jalan Saparua yang tidak ramai sehingga tidak diperlukan.

\section{Dinamika ruang pedestrian Jalan Aceh sisi Saparua Park}

Termasuk tipologi neighborhood mainstreet dengan kepadatan sedang, maka standar lebar keseluruhan ruang pedestrian: $150 \mathrm{~cm}-350 \mathrm{~cm}$. Pada kondisi lapangan ruang pedestrian segmen Jalan Aceh sisi Saparua Park memiliki lebar total $520 \mathrm{~cm}$, terdiri dari frontage zone, pedestrian through zone dan buffer zone.

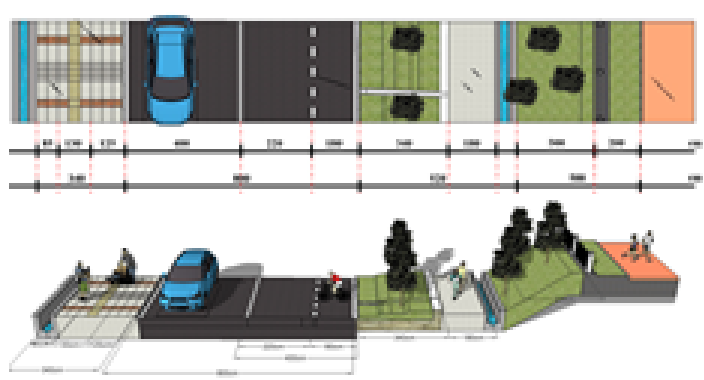

Gambar 5. Ilustrasi dinamika ruang pedestrian Jalan Aceh sisi Saparua Park, Kota Bandung, Provinsi Jawa Barat, Indonesia 
Frontage zone: zona ini menyatu dengan zona pedestrian through zone yang memiliki lebar $180 \mathrm{~cm}$, dengan hitungan pembagian $120 \mathrm{~cm}$ bagi pedestrian through zone dan sisanya $60 \mathrm{~cm}$ bagi frontage zone, maka sudah memenuhi standar. Namun sebaiknya dilengkapi perbedaan material lantai.

Pedestrian through zone: lebar zona jalur pedestrian ini $180 \mathrm{~cm}$, sudah memenuhi standar. Tidak dilengkapi pola guiding block, maka belum memenuhi standar.

Street furniture zone: tidak terdapat zona street furniture namun memungkinkan untuk disediakan, dengan menggunakan ruang tanaman pada buffer zone yang cukup lebar yaitu $340 \mathrm{~cm}$.

Buffer zone: diperuntukan bagi tanaman dengan ukuran yang cukup lebar, $340 \mathrm{~cm}$. Dapat dimanfaatkan dengan membaginya sebagian menjadi street furniture zone.

\section{Dinamika ruang pedestrian Jalan Banda sisi Saparua Park}

Termasuk tipologi neighborhood mainstreet dengan kepadatan sedang, maka standar lebar keseluruhan ruang pedestrian: $150 \mathrm{~cm}-350 \mathrm{~cm}$. Pada kondisi lapangan memiliki lebar keseluruhan ruang pedestrian $360 \mathrm{~cm}$, terdiri dari pedestrian through zone dan buffer zone, masingmasing memiliki lebar $180 \mathrm{~cm}$.

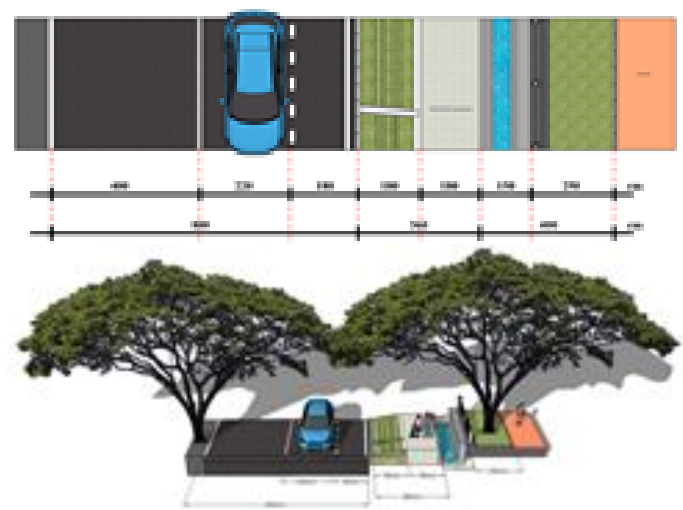

Gambar 6. Ilustrasi dinamika ruang pedestrian Jalan Banda sisi Saparua Park, Kota Bandung, Provinsi Jawa Barat, Indonesia

Frontage zone: zona ini menyatu dengan zona jalur pedestrian. Sudah memenuhi standar. Sebaiknya dilengkapi perbedaan pola material lantai.

Pedestrian through zone: lebar zona jalur pedestrian ini $180 \mathrm{~cm}$, sudah memenuhi standar. Tidak ditemukan pola lantai guiding block material bagi penyandang disabilitas. Street furniture zone: tidak ditemukan zona street furniture. Buffer zone: berupa ruang tanaman dengan lebar $180 \mathrm{~cm}$.

\section{Dinamika ruang jalur sepeda segmen Jalan Ambon sisi Saparua Park}

Lebar total jalur sepeda pada Jalan Ambon $180 \mathrm{~cm}$, memiliki lebar $60 \mathrm{~cm}$ melebihi standar, desain yang baik.

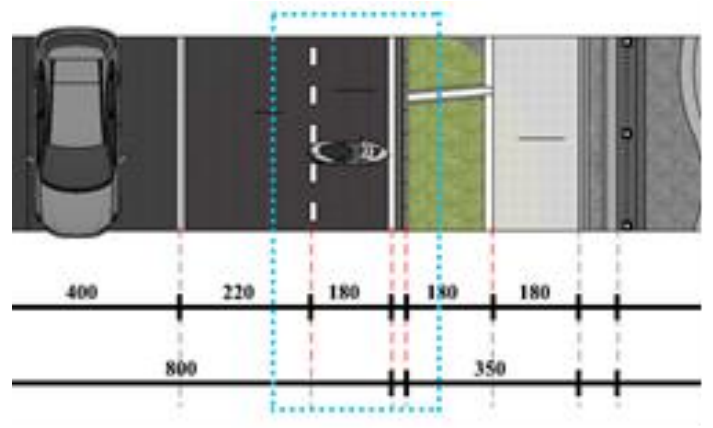

Gambar 7. Ilustrasi dinamika ruang jalur sepeda segmen Jalan Ambon sisi Saparua Park, Kota Bandung, Provinsi Jawa Barat, Indonesia

Pada kondisi nyata jalur sepeda di Jalan Ambon dijadikan tempat parkir sepeda motor sehingga menghalangi akses jalur para pengguna sepeda, shared space tidak memungkinkan memiliki lebar $350 \mathrm{~cm}$ mengingat keterbatasan ruang jalan yaitu $600 \mathrm{~cm}$ yang difungsikan bagi fungsi dua lajur kendaraan yang saling berlawanan arah. Jalur khusus sepeda sudah ditandai dengan garis putus-putus tanda pemisah lajur kendaraan bermotor yang memenuhi standar.

Dinamika ruang jalur sepeda segmen Jalan Saparua sisi Saparua Park

Lebar total jalur sepeda pada Jalan Saparua $180 \mathrm{~cm}$, memiliki lebar $60 \mathrm{~cm}$ melebihi standar, desain yang baik. Jalur sepeda berada di sisi pedestrian Saparua Park namun dijadikan tempat parkir sepeda motor sehingga menghalangi akses pengguna sepeda, shared space memungkinkan dengan opsi penutupan jalan, mengingat jalan Saparua merupakan jalan lingkungan yang berada di dalam ring Jalan Ambon dan tidak dilalui oleh jalur Angkot. 


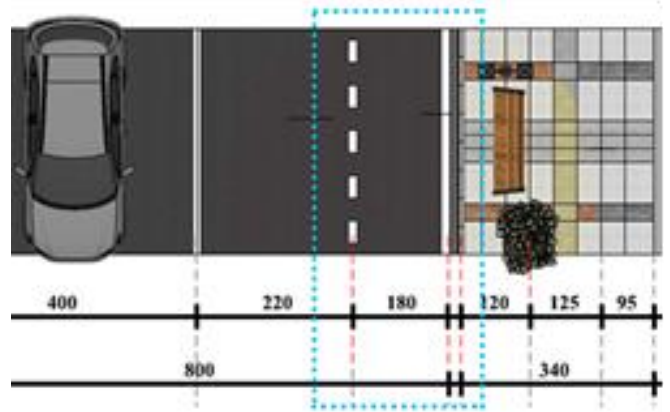

Gambar 8. Ilustrasi dinamika ruang jalur sepeda segmen Jalan Saparua sisi Saparua Park, Kota Bandung, Provinsi Jawa Barat, Indonesia

Jalur khusus sepeda sudah ditandai dengan garis putus-putus tanda pemisah lajur kendaraan bermotor yang memenuhi standar.

Dinamika ruang jalur sepeda segmen Jalan Aceh sisi Saparua Park

Lebar total jalur sepeda pada Jalan Aceh $180 \mathrm{~cm}$, memiliki lebar $60 \mathrm{~cm}$ melebihi standar, desain yang baik.

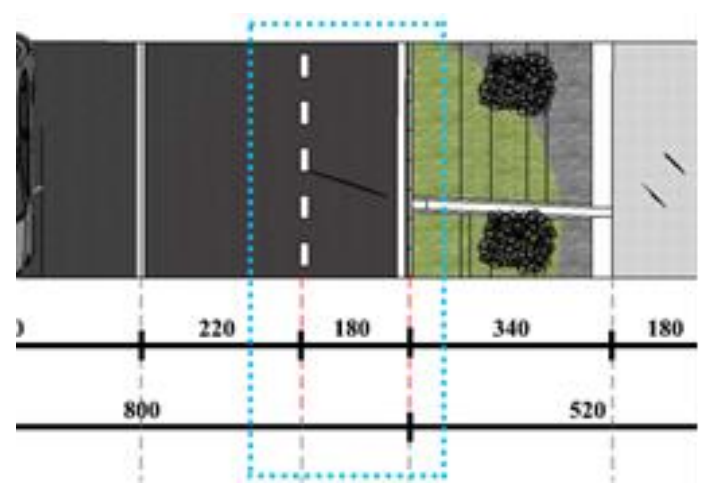

Gambar 9. Ilustrasi dinamika ruang jalur sepeda segmen Jalan Aceh sisi Saparua Park, Kota Bandung, Provinsi Jawa Barat, Indonesia

Penempatan jalur khusus sepeda berada tepat disamping trotoar sisi pedestrian Saparua Park, kondisi jalur sepeda lancar tidak terhalangi adanya parkir kendaraan pada zona shared space, segmen Jalan Aceh merupakan salah satu jalan yang dilalui oleh angkot, desain dan kondisi lapangan sudah memenuhi standar. Jalur khusus sepeda sudah ditandai dengan garis putus-putus tanda pemisah lajur kendaraan bermotor yang memenuhi standar.
Dinamika ruang jalur sepeda segmen Jalan Banda sisi Saparua Park

Lebar total jalur sepeda pada Jalan Banda $180 \mathrm{~cm}$, memiliki lebar $60 \mathrm{~cm}$ melebihi standar, desain yang baik.

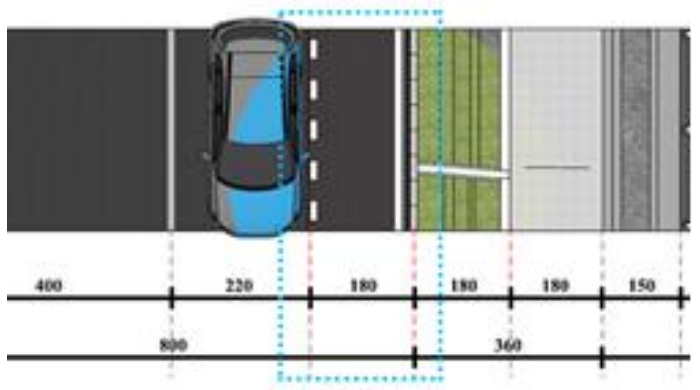

Gambar 10. Ilustrasi dinamika ruang jalur sepeda segmen Jalan Banda sisi Saparua Park, Kota Bandung, Provinsi Jawa Barat, Indonesia

Penempatan jalur khusus sepeda berada tepat di samping trotoar sisi pedestrian Saparua Park, kondisi jalur sepeda lancar tidak terhalangi adanya parkir kendaraan pada zona shared space, segmen Jalan Banda merupakan salah satu jalan yang dilalui oleh angkot, desain dan kondisi lapangan sudah memenuhi standar. Jalur khusus sepeda sudah ditandai dengan garis putus-putus tanda pemisah lajur kendaraan bermotor yang memenuhi standar.

Dinamika jaringan khusus antar ruang terbuka publik di sekitar Saparua Park

Pada sebuah kawasan kota yang aktif ditandai dengan adanya jaringan jalur sepeda yang menghubungkan antar ruang terbuka publik ataupun tempat-tempat penting lainnya antara satu sama lain. Sementara berdasarkan pengamatan pada kawasan studi, pada saat ini kawasan di sekitar Saparua Park belum memiliki jaringan jalur sepeda yang secara khusus diperuntukan bagi aktivitas fisik dan rekreasi yang terintegrasi menghubungkan antar ruang terbuka publik di dalam kawasan.

\section{Dinamika bentukan ruang bagi fasilitas transportasi massal di Saparua Park}

Halte angkot ditemukan pada Jalan Banda sekitar 400meter dari Saparua Park. Jarak antara halte angkutan kota dengan gerbang masuk utama Saparua Park ini tidak lebih dari 500 meter, sudah berada di dalam rasio batas fisik berjalan kaki dari satu titik ke titik lainnya dalam waktu tempuh 6 menit (Gehl 2007). Berdasarkan 
pengamatan di lapangan, lokasi Saparua Park dilalui oleh beberapa rute angkutan kota (angkot) yang melewati ruas Jalan Banda dan Jalan Aceh yang merupakan jalan kolektor sekunder. Namun Saparua Park belum memiliki halte perhentian umum pada tapaknya, sebaiknya disediakan mengingat Saparua Park sudah menjadi salah satu tujuan dan pusat aktivitas masyarakat di Kota Bandung.

Selain hal tersebut, data kuesioner menunjukan bahwa 60 dari 100 orang responden memilih untuk mempergunakan sepeda motor pribadi sementara pengunjung yang memilih untuk menggunakan kendaraan umum, sepeda, dan berjalan kaki masih dibawah 20 orang. Sebenarnya Saparua Park sudah memiliki jaringan transportasi yang terkoneksi dengan baik, namun faktanya hal ini tidak menjamin terciptanya gaya hidup aktif karena pemakaian transportasi umum sangat minim dipergunakan masyarakat. Terbentuknya gaya hidup aktif hanya dapat terwujud apabila masyarakat kota memaknai dan menjalani kesehariannya sebagai individu yang bergerak didalam sebuah sistem tata kota dengan konektivitas dan aksesibilitas yang tinggi, ditunjang oleh sarana prasarana yang nyaman.

\section{Kesimpulan}

\section{Ruang pedestrian Jalan Ambon di sisi Saparua Park}

Berdasarkan hasil wawancara terhadap 100 responden pengunjung Saparua Park, ternyata kebutuhan fungsi kuliner merupakan salah satu alasan mereka memilih untuk mengunjungi Saparua Park dibandingkan dengan taman kota lainnya. Kegiatan kuliner merupakan aktivitas pilihan yang terkait dengan aktivitas olahraga maupun rekreasi. Sebagai solusi, Saparua Park masih memiliki ruang-ruang terbuka yang belum begitu terolah didalam tapaknya, sehingga dapat dimanfaatkan sebagai wadah bagi fungsi kebutuhan kuliner.

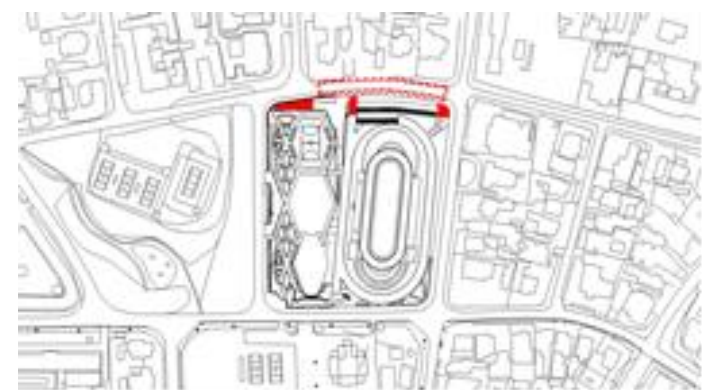

Gambar 11. Ilustrasi penempatan alokasi ruang bagi fungsi kuliner

Selain itu pembangunan teras diatas jalan Ambon sebagai alokasi ruang pedagang kaki lima (PKL) juga dapat diperhitungkan. Dengan adanya alokasi maka tidak ada lagi kendaraan yang terparkir menghalangi jalur khusus sepeda dan tidak adalagi pedangan kaki lima (PKL) yang menghalangi para pejalan kaki.

\section{Ruang pedestrian Jalan Saparua di sisi Saparua Park}

Berdasarkan hasil analisa, ruang pedestrian Saparua Park sisi Jalan Saparua telah memiliki bentukan desain yang baik dan sesuai dengan prinsip-prinsip desain aktif, maka sampai sejauh ini masukan terhadap desain ruang pedestrian segmen Jalan Saparua tidak diperlukan, kondisi tersebut patut dipertahankan.

\section{Ruang pedestrian Jalan Aceh di sisi Saparua Park}

Ruang pedestrian memiliki dua zona, yaitu zona pedestrian through zone dan zona buffer zone. Pada zona pedestrian through zone sebaiknya dilengkapi oleh pola lantai guiding block sebagai material lantai pembantu orientasi kaum difabel. Masukan kedua yaitu bagi zona buffer zone yang memiliki lebar $340 \mathrm{~cm}$ yang pada saat ini hanya dimanfaatkan bagi area tanaman untuk sebaiknya dapat dikembangkan sehingga memiliki ruang bagi zona street furniture.

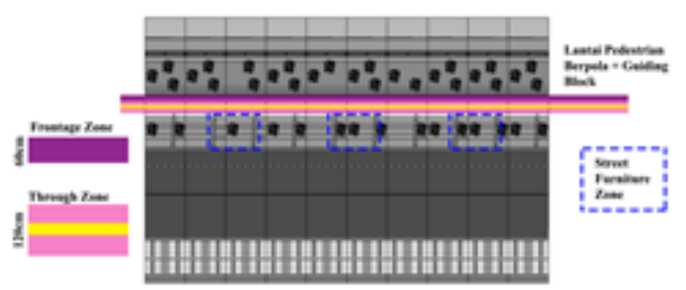

Gambar 12. Ilustrasi prinsip bentukan desain pada ruang pedestrian Jalan Aceh sebagai suatu pedoman desain 
Keberadaan zona street furniture memungkinkan untuk disediakan dengan cara memanfaatkan sebagian ruang tanaman pada zona buffer zone yang memiliki lebar $340 \mathrm{~cm}$.

\section{Ruang pedestrian Jalan Banda di sisi Saparua Park}

Ruang pedestrian memiliki dua zona, yaitu zona pedestrian through zone dan zona buffer zone. Pada zona pedestrian through zone sebaiknya dilengkapi oleh pola lantai guiding block sebagai material lantai pembantu orientasi kaum difabel.

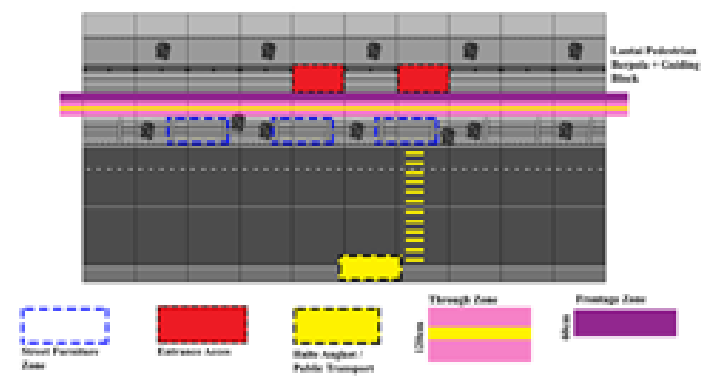

Gambar 13. Ilustrasi prinsip bentukan desain pada ruang pedestrian Jalan Banda sebagai suatu pedoman desain

Pada zona buffer zone dapat dilakukan pembagian petak ruang tanaman bagi ruang zona street furniture, berkaitan dengan itu kemudian menyediakan akses masuk dari ruang pedestrian Jalan Banda terhadap tapak Saparua Park agar menunjang aksesibilitas, selanjutnya berdekatan dengan akses masuk tersebut disediakan halte perhentian transportasi massal.

\section{Jalur sepeda di sekeliling Saparua Park}

Secara garis besar sebenarnya keberadaan jalur sepeda pada keempat segmen jalan yang mengelilingi Saparua Park perlu diapresiasi dan sudah medukung terciptanya gaya hidup active living, namun kondisi nyata masyarakat secara umum masih belum sadar akan pentingnya menggunakan sarana umum. Adanya parkir kendaraan yang menghalangi jalur sepeda, tidak terintegrasinya jalur sepeda tersebut terhadap ruang terbuka publik lainnya atau tempat-tempat populer lainnya mengakibatkan jalur tersebut tidak nyaman sehingga tidak menjadi pilihan utama masyarakat dalam bertransportasi. Hal yang dapat dilakukan adalah mempertegas jalur khusus sepeda dengan adanya netting pada garis putus-putus notasi ruang jalur sepeda, serta mewarnai keseluruhan elemen lantai jalur sepeda secara konsisten disepanjang jalur tersebut.

\section{Jalur khusus perjalanan aktif}

Saran atau masukan ketiga yaitu diberlakukannya jaringan jalur sepeda yang menghubungkan beberapa ruang terbuka publik maupun tempat penting lainnya yang ada di sekitar Saparua Park.

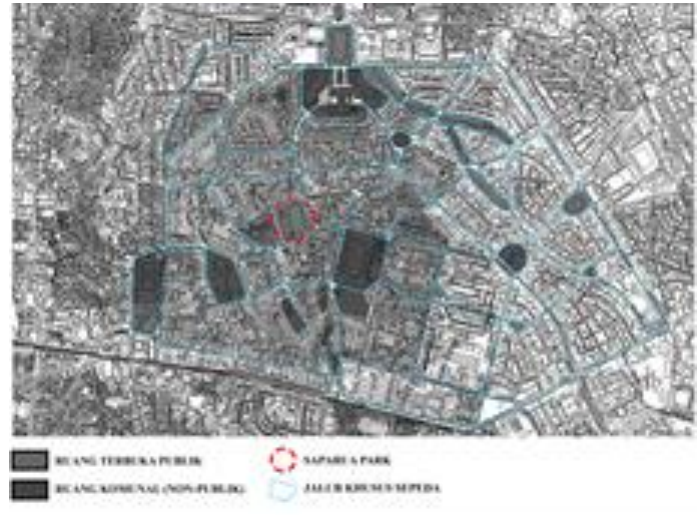

Gambar 14. Ilustrasi jalur khusus perjalan aktif di sekitar Saparua Park

\section{Ruang fasilitas transportasi massal di sekitar Saparua Park}

Pada saat ini pada tapak Saparua Park belum terdapat halte angkutan kota, sebagai salah satu tempat tujuan yang ramai dikunjungi masyarakat Kota Bandung sebaiknya halte angkutan kota terdapat pada tapak Saparua Park. Perletakan halte angkot pada tapak Saparua Park sebaiknya diletakan pada sisi segmen jalan Banda karena merupakan segmen jalan yang paling banyak dilalui oleh rute angkot dari keempat segmen jalan yang mengelilingi tapak Saparua Park.

\section{Referensi}

Anderson W G, R. 1991. 'BICYCLE FACILITY MANAGEMENT. ON THE ROAD'. TRANSAFETY REPORTER.

Carmona, Matthew, Claudio de Magalhães, and Leo Hammond. 2008. Public Space: The Management Dimension. Public Space: The Management Dimension. https://doi.org/10.4324/9780203927229.

Centers for Disease Control and Prevention. 2014. 'National Diabetes Statistics Report: Estimates of Diabetes and Its Burden in the United States'. US Department of Health and 


\section{Human Services.}

Firdaus Prayogi, Sigit, Budi Isdianto, and Muh. Ihsan. 2014. 'EKSPERIMEN TEORI HUMAN CENTERED DESIGN PADA ELEMEN FISIK TAMAN KRESNA KOTA BANDUNG'. Jurnal Sosioteknologi. https://doi.org/10.5614/sostek.itbj.2014.13.3. 5.

Gehl, Jan. 2007. 'Public Spaces for a Changing Public Life'. In Open Space: People Space. https://doi.org/10.4324/9780203961827.

Giles-Corti, Billie, Hannah Badland, Sarah Foster, Suzanne Mavoa, Carolyn Whitzman, and Gavin Turrell. 2014. 'Healthy Cities'. In Australian Environmental Planning: Challenges and Future Prospects. https://doi.org/10.4324/9781315813110.

Hendrawan, Christianto, and Yohanes Basuki Dwisusanto. 2017. 'Konsep Active Living Dalam Perancangan Jalur Pedestrian, Studi Kasus: Jalan L. L. R. E. Martadinata (Riau), Bandung, Jawa Barat'. ARTEKS: Jurnal Teknik Arsitektur 2 (1): 15-32. https://doi.org/10.30822/arteks.v2i1.38.

Jackson, Laura E. 2003. 'The Relationship of Urban Design to Human Health and Condition'. Landscape and Urban Planning. https://doi.org/10.1016/S01692046(02)00230-X.

Kamel Boulos, Maged N., and Najeeb M. AlShorbaji. 2014. 'On the Internet of Things, Smart Cities and the WHO Healthy Cities'. International Journal of Health Geographics. https://doi.org/10.1186/1476-072X-13-10.

Lee, Karen K. 2012. 'Developing and Implementing the Active Design Guidelines in New York City'. Health and Place. https://doi.org/10.1016/j.healthplace.2011.09. 009.

Lefebvre, Henri. 1992. The Production of Space. Edited by Donald Nicholson Smith. The Production of Space. 1 edition. United States: Wiley-Blackwell.

Liem, Yoseph, and Reginaldo Chistophori Lake. 2018. 'Pemaknaan Ruang Terbuka Publik
Taman Nostalgia Kota Kupang'. ARTEKS: Jurnal Teknik Arsitektur 2 (2): 149-58. https://doi.org/10.30822/arteks.v2i1.48.

Lynch, Kevin. 1960. The Image of the City. Harvard-MI. United States: MIT Press.

Martin, Wortmann, and Wortmann Martin. 2007. 'United Nations Human Settlements Programme (UN-HABITAT)'. In Max Planck Encyclopedia of Public International Law. https://doi.org/10.1093/law:epil/9780199231 690/e1715.

Mberu, Yuliana Bhara, and Yohanes Djarot Purbadi. 2018. 'Makna Ruang Jalan Di Kota Lama Kupang Menurut Pengguna Ruang Pedagang Informal Dan Formal'. ARTEKS: Jurnal Teknik Arsitektur 3 (1): 79-100. https://doi.org/10.30822/arteks.v3i1.56.

Pradono, Budi. 2019. 'The Interiority of Proximity Between Nature and Architecture in Contemporary and Tropically Context with Cases Studies'. ARTEKS: Jurnal Teknik Arsitektur $\quad 3 \quad$ (2): $\quad 129-44$. https://doi.org/10.30822/arteks.v3i2.63.

Pucher, John, and Ralph Buehler. 2010. 'Walking and Cycling for Healthy Cities'. Built Environment. https://doi.org/10.2148/benv.36.4.391.

Subroto, Tarcicius Yoyok Wahyu. 2019. 'Koeksistensi Alam Dan Budaya Dalam Arsitektur'. ARTEKS: Jurnal Teknik Arsitektur 3 (2). https://doi.org/10.30822/arteks.v3i2.60.

Watson, Donald, Alan Plattus, and Robert Shibley. 2003. Standards for Urban Design. New York: McGraw-Hill.

WHO. 2011. 'WHO | Obesity and Overweight'. World Health Organisation Media Centre Fact Sheet No. 311.

Widodo, Johannes. 2019. 'Human, Nature, And Architecture'. ARTEKS: Jurnal Teknik $\begin{array}{llll}\text { Arsitektur } & 3 & \text { (2): } & 145-48 .\end{array}$ https://doi.org/10.30822/arteks.v3i2.65.

2013. Urban Street Design Guide. Urban Street Design Guide. https://doi.org/10.5822/978-161091-534-2. 
ARTEKS : Jurnal Teknik Arsitektur, Volume. 4, Issue 1, December 2019 eISSN 2541-1217; pSSN 2541-0598 